\title{
Gender Representation and Framing of Malaysian Women: A Study of Feature Articles in Female Magazine
}

\author{
Yang Lai Fong \\ Associate Professor, Xiamen University Malaysia
}

Shammah Esther Chiriseri Nyathi

\begin{abstract}
The media are powerful tools for communication and socialization. Through media representations, audience establishes a way of making sense about themselves and the world. Magazines are one of the important sources of socialization as well as popular cultural representation. An important focus of the magazines in their portrayal of gender is the concept of masculinity and femininity. Masculinity and femininity are a set of attitudes, roles, norms and values of male and female in society. This study used framing as the theoretical framework and content analysis as the research method to examine the representation of Malaysian women, as well as the portrayal of masculinity and femininity in Female magazine. It was found that Female magazine did not place any limit, traditional boundary or stereotype on its representation of Malaysian women. Instead, the magazine encouraged female readers to pursue for their passions, emulating both the feminine and masculine characteristics that are essential to be successful.
\end{abstract}

Keywords: Framing, Femininity, Masculinity, Women's Magazine, Gender Representation

\section{Introduction}

The root of gender roles difference stems from one's biological make up and it is through these differences that social contexts and patterns are developed. Gender displays are the rituals of gender behaviors that could be used to interpret social reality (Jhally, 2011). The media are powerful tools for communication and socialization. Through media representations, audience establishes a way of making sense about themselves and the world (Govender et al, 2014). An important focus of the media in their portrayal of gender is the concept of masculinity and femininity. O'Shaughnessy and Stadler (2006) asserted that the notion of gender is based on social and cultural roles, personality traits and behaviors that are considered socially acceptable for men and women in relation to concepts of masculinity and femininity. Masculinity and femininity are a set of attitudes, roles, norms and values of male and female in society. Masculinity is usually associated with the traditional male roles of being strong, assertive and ambitious, while femininity is often related to motherhood, relationship development and family-oriented (Jian, Pettey, Rudd and Lawson, 2007).

According to Van Gorp (2007), media framing of women is done through the selection of words, images, metaphors, descriptions and visuals. Despite the changes in their societal roles in modern day, it was found that women are still being portrayed in undesirable and stereotypical manners by media (Tartaglia and Rollero, 2015). Arauna and Tarragona (2013) also criticized that women have for the longest time been sexualized and displayed as sexual objects. Images of women in media have always highlight specific body parts such as breasts, backside, hair, lips and eyes. In their study on women's role stereotypes in magazine advertisements, Lindquist, Steinfeldt and Belonax (2015) found that teenage girls have always been depicted as being passive, materialistic, beauty and dating and have little or no interest in academics or careers. Furthermore, Jhally (2011) also observed that women in print media were found to be posing as touching themselves, cuddling an object, lying on the floor, sitting on a bed or chair, eyes closed, confused, weak, body contorted, dressed like a child, holding an object or a man for support, sexy and sexually available - all which are signs or symbols of submission and powerlessness and placing emphasis on her beauty and sexual appeal.

Magazines are popular cultural forms of representation. In recent years, studies have also been conducted in several countries to investigate the portrayal of women in magazines. For example, Ramasubramaniam 
and Jain (2009) pointed out that India is a classic example whereby male-controlled society expects women to follow the rules given by the dominant male society. As a result, Indian media portrayed women in stereotypical roles and depicted them as caring housewives or as sexual objects. In addition, Grover and Hundal (2014) stated that in India, women play a decorative role in advertisements. They were showed as adorning the product and are meant to serve as a sexual attractive stimulus. Women are also found to be playing a recreational character, in which they are doing a nonworking role such as reading, hiking and jogging. It was also found that women were depicted in domestic role, such as performing house works or looking after children.

Basnyat and Chang (2014) found that in Singapore, women's magazines represented femininity by focusing on woman's body. In American and Swedish magazines, Lindquist et al (2015) found that men are usually depicted as more physically and leisurely active than women. Furthermore, men were characterized in more important occupational roles and being superior to women.

In Malaysia, Kathiraveloo (2001) examined the portrayal of women in magazine advertisements. The findings showed that women were depicted in stereotypical positions and mostly used for selling products through an emotional appeal. The author also found that advertisers used women as sex objects to attract attention of the reader and it was found that women were used where they had no relevance to the product being advertised (Kathiraveloo, 2001). In their analysis of a Malaysian edition of foreign magazines, Alagappar and Selvaratnam (2014) found that appearance and beauty were the main topics emphasized by the magazines. In addition, the authors found that women's traditional gender roles were reinforced by the magazines, whereby women were defined by the husband and children in their lives. Hashim et al (2016) investigated the portrayal of women's relationships by two Malaysian magazines. It was found that women's relationships and connections with their spouse, kids and family were being emphasized.

It is interestingly to note that Hofstede (2011) found that women's values when compared across societies seemed to be similar, whereas with men the geographical location played a major role in the masculinity levels of assertiveness and competitiveness. In addition, it is also noteworthy that literature on portrayal of masculinity by Malaysian media is sparse.

\section{Status of Women in Malaysia}

Malaysia is a country aiming to achieving high income status. Women's employment $(4.5 \%)$ in the country grew at a faster pace compared to male employment $(2 \%)$ in 2010-2016. The highest rate of growth in female employment was observed in health and hospitality services, as well as the public sector. When compared to some of the regional economies, however, Malaysia's labour force participation rate for females remains just above $54 \%$. In contrast, males' participation rate in employment is about $80 \%$ (International Monetary Fund Blog, 2 April 2018).

Some initiatives undertaken by the Malaysian government to promote equality for women include enhancement of national machinery for women's development, an increase in women's involvement in policy decisionmaking, safe guards on women's rights in health, education and social wellbeing, removal of legal constraints and gender discrimination (Moustafa, 2013). These areas were highlighted because women have been discriminated when it concerns marriage, family and divorce.

In addition, there are several nongovernmental organizations in Malaysia that address the issue of gender inequalities and call for reform. Sisters in Islam (SIS) was established in 1987 to deal with the issue that Muslim women in Malaysia found themselves facing syariah laws and policies made in the name of Islam that they think are unjust to women. SIS has been working and studying the Quran to see how women can have rights under Islam and no longer be marginalized. The NGO also offers legal aid and counselling for issues where women usually have little or no say due to lack of legal knowledge about marriage, family, divorce or domestic abuse. In addition, All Women's Action Society (AWAM) is another group that came about to address the issues of domestic violence. AWAM advocates for women's rights and have also set up a help line that offer legal assistance and counselling. 
While women's rights and equality has been undergoing reform in Malaysia and has made considerable progress over the last few years (World Bank, 2011), the literature on media representation of Malaysian women is rather sparse. It is also important to note that there is little if not no study using media or communication theory to analyze gender representation in media. By using framing as the theoretical framework for this study, it would complement previous studies from a communication perspective.

\section{Research Objective, Research Questions and Significance of the Study}

Considering the impact of media in socialization, progress of women's rights and equality in Malaysia, as well as the gap in literature as mentioned above, this study aimed to examine the representation of Malaysian women by magazine.

The following research questions were raised for examination in this study:

RQ1: What were the frames employed by the feature articles in women's magazine?

RQ2: How did the women's magazine represent femininity?

RQ3: How did the women's magazine represent masculinity?

The current study is different from the previous studies as it focused on the representation of Malaysian women in Female Magazine. This is a magazine that has yet to be analyzed when it comes to studies done within the geographical location of Malaysia. The current study also focused on the text of the magazine, while previous studies have focused on the imagery and visual aspects. In addition, this study contributed to an understanding of how Malaysian women were defined by women's magazines through the perspectives of femininity and masculinity.

\section{Theoretical Framework}

Milkie (2002) stressed that media frames suggest, create, and sustain everyday practices of femininity and masculinity stratification. These dominant ideologies then become interpretative frameworks of a social group, which play a significant role in perpetuating dominant ideologies (Thornham, 2007).
The origins of framing lie in the fields of cognitive psychology and anthropology. It was later applied in the fields of sociology, economics, linguistics, social-movements research, policy research, communication science, political communication, public relation research and health communication (Bryant and Miron, 2004). In the filed of media studies, Tuchman (1978) and Gitlin (1980) were the two earliest scholars to introduce framing to communication research. They asserted that news is a social construction, and the media have significant effect on what is perceived by the public to be reality. They also claimed that media representation often coincides with the definition that is provided by the holder of power, or the elites in the society. In this way, the media allow this dominant group to be opinion leaders to define events or issues, and subsequently shaping others' values, attitudes and opinions.

According to Entman (1993), any communicative text, either informative or persuasive, requires narrative structures to organize its discourse. From this approach, framing can be defined as a process in which some aspects of reality are selected, and given greater emphasis or importance, so that the problem is defined, its causes are diagnosed, moral judgments are suggested and appropriate solutions and actions are proposed. In addition, Griffin (2003) considered framing as "the process of calling attention to some aspects of reality while obscuring others, which might lead to different reactions." Scheufele and Tewksbury (2007) defined framing as "the selection of a restricted number of thematically related attributes for inclusion in the media agenda when a particular object is discussed."

Chong and Druckman (2007) found that communication scholars generally apply the term "frame" in two ways. First, a media frame refers to the words, images, phrases and presentation styles that a media outlet uses when relaying information about an issue or event to an audience. The chosen frame reveals what the media outlet sees as relevant to the topic at hand. Scheufele and Tewksbury (2007) regarded this way of framing as a macro level construct. They mentioned that at a macro level, framing refers to modes of presentation that communicators use to present information in a way that resonates 
with existing underlying schemas among their audience.

At a micro level, frame of thought or an individual frame refers to an individual's cognitive understanding of a given situation (Chong and Druckman, 2007). Unlike media frame that reflects a media outlet's emphasis, frames in thought refer to what an audience member believes to be the most salient aspect of an issue. Scheufele and Tewksbury (2007) considered this way of framing as a micro level construct, which describes how people use information and presentation features regarding issues as they form impressions. It is well documented that when news frame is used appropriately, they affect readers' interest, attention, interpretation and comprehension of the news (De Vreese and Semetko, 2002; Tewksbury, Jones, Peske, Raymond, and Vig, 2000; Zillman, Chen, Knobloch and Callison, 2004).

Discussing about competing and multiple frames, Scheufele and Tewksbury (2007) asserted that audience will engage in a systematic break down of the information by comparing the relative strength of different frames in competitive situations, leading them to conclude differently on the idea being promoted by the frames. Interestingly, Chong and Drukman (2007) also found that repetition of frames have a greater impact on those who are less knowledgeable on the subject matter and also on those who are more focused to peripheral cues. Other factors that play a key role in frames are frequency, accessibility and relevance. Frequency is defined as the number of times the media repeats the particular frame being presented. The greater the repetition, the greater the force, impact or emphasis. Accessibility and repetition go hand in hand as the accessibility improves repetition. While relevance refers to the core of the subject matter based on peripheral cues, this refers to the stimuli that will persuade individuals on a particular subject matter.

\section{Method}

This study employed content analysis as the research method. The magazine chosen to be analyzed was the Female magazine (Malaysian version), which was launched in Malaysia in 1974, and published in English-language. Female aims to present to its readers, whom made up of mainly urban Malaysian women, both local and international inspirations. The magazine offers $40 \%$ of its content focusing on beauty, makeup products, hair, testimonial for beauty products as well as beauty advice for women. Fashion related topics constitute 30\% of content in Female, where it looks at both international and local fashion inspirations. Lifestyle related topics, which contribute $15 \%$ to the magazine content focus on food, travel, music and suggestions for holiday destinations. Quick tips and suggestions offered by the editor make up $5 \%$ of the magazine content, while the remaining $10 \%$ is everything else that the magazine considers as important topics for the modern women (Blu Inc, 2016).

The Female magazine enjoys 50,000 circulation and 164,000 readership in Malaysia, making it one of the most popular and prominent women magazines in Malaysia. The targeted group for the magazine is the smart, savvy and young women readers. Majority $65 \%$ of Female readers fall within the age range of 2039 years old, most of them are professionals, managers and top executives. It was also found that $73 \%$ of Female readers have a university degree (Selva, 2016). Furthermore, Female also offers an online version of its magazine, it enables its readers to access to the magazine content and material regardless of their geographical location. The magazine also has an Instagram page and a Facebook page that has 37,000 fans (Blu Inc, 2016).

\section{Sampling and Coding Procedures}

The sample of this study was drawn from January to December 2016. This study examined the feature articles published by the Female magazine, which is also known as Lifestyle Insider. This section was selected as it represents the ideal lifestyle of women. The Lifestyle Insider features a prominent female or male character each month. These characters are inspirational and outstanding figures in their respective field. More importantly, the feature articles highlight the remarkable characteristics, attributes and traits of the individuals. Through this, Female plays an important role in socialization or conveying the values to its women readers.

By using feature articles as the units of analysis, the first research question asked "What were the frames employed by the feature articles in women's magazine?" This study employed the inductive or emergent coding approach for analyzing frames. The 
coding categories were outlined after a preliminary examination of the data. As a result, six categories of frames were identified in this study:

1. Travel - focusing on the unique and exciting traveling experiences.

2. Finances - emphasizing on planning and management of financial.

3. Relationships- discussing about relationships with friends or family.

4. Fashion - highlighting the popular trend in fashion style or dressing.

5. Career - focusing on opportunities for progress and self-development.

6. Politics - discussing topics related to governance, power or public affairs.

The second and third research questions looked into how femininity and masculinity were represented in the feature articles. This study adopted and modified the coding categories suggested by Basnyat and Chang (2014) in their analysis of the representation of femininity in Singaporean women's magazines. For the current study, the representation of femininity and masculinity were investigated from two angles: 1) Extent of representation for each feminine or masculine characteristics; and 2) Types of feminine or masculine characteristics. The extent of representation was measured by the frequency in which each characteristic was presented.

The categories for feminine characteristics used in this study were:

1. Gentle and kind - mild, kind, soft, tender, considerate of others' emotions.

2. Homemaking - manages household and caring for family.

3. Accomplished - takes pride in work and is often very successful in career.

4. Healthy and fit - a strong state of mental and physical wellbeing.

5. Beautiful and fashionable - attractive and good-looking, up to date with fashionable apparel and accessories.

6. Emotion - responses based on feeling rather than knowledge, reasoning or facts.
7. Submissive - meekly obedient and passive, underneath someone in authority.

The masculine characteristics used in this study were:

1. Confident and independent - secure in one's self and own abilities, not being influenced by others in conduct or opinion.

2. Dominant and superior - having power and influence over others, contesting for supremacy, being better or stronger when compared to others.

3. Decisive - able to make a conclusion or decision promptly.

4. Persistent and resistant to pressure resilient and not giving up easily.

5. Active - moves around a lot physically or does lots of things and activity.

\section{Data Analysis and Inter-Coder Reliability}

The 12 feature articles collected from Female magazine was analyzed using descriptive statistics such as frequencies and percentage, as well as qualitative interpretation. To ensure the reliability of the study, a communication graduate was chosen as the second coder. During the training session, the first and second coders coded 4 randomly selected feature articles published by Female magazine in 2016. Disagreements were analyzed and some additional explanations were included to the coding instruction in the code book. Subsequently, inter-coder reliability for this study was established by including all articles coded by the first and second coders. This was equivalent to 12 feature articles published from January to December 2016. Using Holsti's formula (cited in Wimmer and Dominick, 2006), it was found that the inter-coder reliability for frames was $0.96,0.98$ for feminine representation and 0.94 for masculine representation.

\section{Findings and Discussion}

Frames of the Feature Articles

Among the 12 issues of Female magazine published in 2016, $66.6 \%$ of the characters featured in Lifestyle Insider were female, while $33.3 \%$ were male (refer Table 1). The target audience for Female are women and therefore it is only natural that the magazine featured more female characters as it would be more relevant to the audience. 
Table 1: Classification of Character in Feature Articles based on Sex

\begin{tabular}{l|l|l}
\hline Sex & Frequency & Percentage (\%) \\
\hline Male & 4 & 33.33 \\
\hline Female & 8 & 66.67 \\
\hline Total & $\mathbf{1 2}$ & $\mathbf{1 0 0 . 0 0}$ \\
\hline
\end{tabular}

Table 2 shows that "career" is the most salient frame in Female's feature article. It accounted for $37.04 \%$ for the content of the year, followed by "relationships" (25.93\%), "travel" (14.81\%) and "fashion" (14.81\%).

Table 2: Frames of the Feature Articles

\begin{tabular}{l|l|l}
\hline Frame & Frequency & $\begin{array}{l}\text { Percentage } \\
\mathbf{( \% )}\end{array}$ \\
\hline Travel & 4 & 14.81 \\
Finances & 1 & 3.70 \\
Relationships & 7 & 25.93 \\
Fashion & 4 & 14.81 \\
Career & 10 & 37.04 \\
Politics & 1 & 3.70 \\
\hline Total & $\mathbf{2 7}$ & $\mathbf{9 9 . 9 9}$ \\
\hline
\end{tabular}

For example, Sasa Chian was depicted as a well-rounded and accomplished woman.

She is a professional acroyoga instructor after obtaining her qualifications from Acroyoga Montreal. Sasa is currently the only heard-of instructor in the discipline who resides and teaches in Malaysia.

Source: Selvanayagam, V. (2016). Acro Pro. Female (February 2016), p.210.

Meanwhile, Haze Long showed how one does not have to be stuck in the same position and can easily make a change and still be successful at what he or she is doing. She made a transition from being a web developer to a full-time artist.

She has a degree in Film and Animation, was a well-known makeup artist and founded Art Misfits to create opportunities for young street artist.

Source: Selvanayagam, V. (2016). Speed art. Female (May 2016), p.224.

The findings showed that women in Malaysia are courageous in pursuing their dreams and career, while successfully breaking through the traditional gender rules and conventional expectations placed on them by society. The women featured in Lifestyle Insider are not defined by their husband or children but their passion and vision. This findings were contrasting previous study conducted by Grover and Hundal (2014), where the authors found that women were portrayed as holding decorative and recreational roles. Alagappar and Selvarantam (2014) also argued that feminine literature should be revised as it could impact groups of women who are socially conscious. In the case of Female, the magazine deviated from the traditional frames that have been applied on to women by media. It is also important to note that Chong and Drukman (2007) asserted that repetition of frames will have a greater impact on the audience. Therefore, the continuous repetition of the "career" frame seemed to represent modern ideologies and empowerment of women.

When a male figure was featured in Lifestyle Insider, the "career" frame matched traditional expectations of what a successful man should be. This is consistent with a study conducted by Alam (2015), whereby men were found to be dominant, aggressive, decisive, confident as well as ambitious in their career. In the March 2016 issue, Callan C. Green was described as an extremely talented man that excels in his career.

I've taken part in many competitions.... I ended up beating my old boss and mentor in the final, which made me feel very honored.

Source: Selvanayagam, V. (2016). The cool mix. Female (March 2016), p.263.

It is significant to note that the "relationship" frame was only highlighted when the characters featured in Lifestyle Insider were female. For example, Angeline Khoo made reference to her brother, who is very close to her heart. She also mentioned how she drew inspiration from her mother. It was reported that these strong family ties have influenced her to become who she is, while influencing her in several major decisions that she has made. This frame encouraged women to look up to their family for inspiration. Goffman (1974) defined this framing process as the social framework or mental schema that influence readers to re-organize their experiences. 
My brother is autistic and my mum is involved in women's rights, so I wanted to be part of a business that could help people with special needs. I want to create work opportunities.

Source: Yen, A. (2016). Fiery fashion. Female (November 2016), p.197.

\section{Representation of Femininity}

As recorded in Table 3, the most frequently represented feminine characteristic in the feature articles is "accomplished" (30.61\%), followed by "gentle and kind" (18.37\%) and "emotional" (18.37\%).

Table 3: Representation of Feminine Characteristics

\begin{tabular}{l|l|l}
\hline $\begin{array}{l}\text { Feminine } \\
\text { Characteristic }\end{array}$ & Frequency & $\begin{array}{l}\text { Percentage } \\
\mathbf{( \% )}\end{array}$ \\
\hline Gentle and kind & 9 & 18.37 \\
\hline Homemaking & 2 & 4.08 \\
\hline Accomplished & 15 & 30.61 \\
\hline Healthy and fit & 3 & 6.12 \\
\hline $\begin{array}{l}\text { Beautiful and } \\
\text { fashionable }\end{array}$ & 6 & 12.24 \\
\hline Emotion & 9 & 18.37 \\
\hline Submissive & 5 & 10.20 \\
\hline Total & $\mathbf{4 9}$ & $\mathbf{9 9 . 9 9}$ \\
\hline
\end{tabular}

Since the most salient frame found in Lifestyle Insider was "career", it was not surprising that "accomplished" was found to be the most frequently depicted feminine characteristics. Featuring Sasa Chian, Lifestyle Insider illustrated the characteristic of an accomplished female.

Besides acroyoga, she's also a pro in ballet, street jazz, contemporary, aerial and latin dancer, contact improvisation and manasa yoga

Source: Selvanayagam, V. (2016). Acro Pro. Female (February 2016), p.210.

In addition, Dinda Puspitasari was described "knows no bounds" in her pursue of dream.

Her quirky style and personality are matched by Dinda Puspitasari, its illustrator, whose talent in drawing knows no bounds.

Source: Chan, T. (2016). Model fever. Female (September 2016), p.216.
When highlighting the characteristics of "gentle and kind", Lifestyle Insider reported that Angeline Khoo is involved in business because she wishes to help people with needs. More importantly, it was stressed that it came from her kindness, love and compassion for her autistic brother. It was also reported that Angeline followed her mother's footsteps in kindness and caring for others. Her mother is actively involved in women's rights and charity works. It influenced Angeline to create employment opportunities for the marginalized groups.

Artisans are marginalized women from poor families and single mothers. We seek out women who don't have many employment opportunities, engage them and teach them sewing skills.

Source: Yen, A. (2016). Fiery fashion. Female (November 2016), p.197.

Hofstede (1998) also stressed that women are seen as those who cares for others. The women who exude this characteristic have been found to use their strength to contribute to community.

Through the "emotion" characteristic, Diana Rikasari was considered to be in touch with emotions. She mentioned that her favorite quote was:

When people hate you, love them back because I think its something very important for us to achieve as humans.

Source: Chan, T. (2016). Model fever. Female (September 2016), p.216.

In addition, Angeline shared that she named her whole brand after a beautiful event that happened in her life. The event left an impactful "emotion" on her that she decided to make it a permanent memory in her life.

The name is derived from a pink, sweet yet spicy cake she received from a secret admirer once.

Source: Yen, A. (2016). Fiery fashion. Female (November 2016), p.197. 


\section{Representation of Masculinity}

While female characters were featured relatively much more by Lifestyle Insider, they were found to be portraying masculine characteristics too as their male counterparts. This findings is consistent with the results recorded by Basnyat and Chang (2014). The authors stated that there was not clear cut between masculinity and femininity nowadays because the roles of men and women in the modern days have been overlapping.

Nonetheless, feminine characteristics, which accounted for 49 appearance times were almost double the extent of appearance for masculine characteristics (25 times) (refer Table 3 and 4). The most frequently seen masculine characteristic was "confident and independent" (32.00\%), followed by "dominant and superior" (24.00\%) and "persistent and resistant to pressure" $(20.00 \%)$.

Table 4: Representation of Masculinity

\begin{tabular}{l|c|c}
\hline $\begin{array}{l}\text { Masculine } \\
\text { Characteristics }\end{array}$ & Frequency & Percentage \\
\hline $\begin{array}{l}\text { Confident and } \\
\text { Independent }\end{array}$ & 8 & 32.00 \\
\hline $\begin{array}{l}\text { Dominant and } \\
\text { superior }\end{array}$ & 6 & 24.00 \\
\hline Decisive and & 5 & 12.00 \\
\hline $\begin{array}{l}\text { Persistent to } \\
\text { resistant } \\
\text { pressure }\end{array}$ & 3 & 20.00 \\
\hline Active & $\mathbf{2 5}$ & $\mathbf{1 0 0 . 0 0}$ \\
\hline Total
\end{tabular}

Haze Long was portrayed as having a high level of self-confidence. When asked on her rehearsal routine she stated:

I only rehearse only when I'm doing something different.

Source: Selvanayagam, V. (2016). Speed art. Female (May 2016), p.224.

Dominance refers to the ability to have power and influence over others. Sasa Chian exhibited this characteristic as Lifestyle Insider portrayed her as dominating the yoga discipline in Malaysia:

Sasa is currently the only heard of instructor in the discipline who resides and teaches in Malaysia.

Source: Selvanayagam, V. (2016). Acro Pro. Female (February 2016), p.210.
The masculine characteristics or "persistent and resistant to pressure" were best represented through the former track cyclist Josiah Ng. It was reported that his family did not believe in him and even wanted to get him to stop pursuing his dream. They gave him an ultimatum to move out. However, he chose to boldly pursuing his dream and move out of his parents' house. To make ends meet, he had to working as a technician to tune pianos and was couch surfing with a friend. The Lifestyle Insider reported that if Josiah did not have the strong determination at the early days, he would not have been able to achieve the outstanding accomplishments today or enjoy the fruitful results.

10 World Cup medals, two World Cup overall titles, Malaysia's first Commonwealth Games medal in cycling and becoming Asia's first Olympic finalist. Josiah has taken a step back and manages his own online market place now.

Source: Selvanayagam, V. (2016). Striking out to success. Female (June 2016), p.198.

As mentioned earlier, the masculine characteristics that were highlighted in Lifestyle Insider were also found among the female counterparts. Nonetheless, the male characters was found to be displaying much more of the masculine characteristics compared to female. Through investigating women's magazine as a platform of gender representation, this study traced the development of changing ideas, understanding and expectations towards femininity and masculinity in society. Images of being a woman have changed from uniform gendered attributes to embracing more masculine characteristics. It was found that the modern femininity incorporates masculine traits into the changing role of being a woman. Basnyat and Chang (2014) also remarked that classifications of femininity have broadened to include certain aspects of positive masculine characteristics. It is no longer an exclusive distinction between femininity and masculinity.

\section{Conclusion}

The media are powerful tools for communication and socialization. Media representation often lead to audience acceptance of media portrayals as normative, expectable and acceptable. The findings of the 
study showed that Female magazine did not place any limit, traditional boundary or stereotype on its representation of Malaysian women. Instead, the magazine encouraged female readers to pursue for their passions, emulating both the feminine and masculine characteristics that are essential to be successful.

This study only focused on the feature section, which is also known as Lifestyle Insider. It analyzed the frames embedded in the feature articles, as well as the ideologies on femininity and masculinity. For future studies, analyses of other sections of the magazine could be conducted to investigate whether similar frames are presented, and whether they are consistent narrative throughout the whole magazine. In addition, examination of none feminine-based magazines could be carried out to see how women are represented or framed.

This study employed content analysis as the research method. This means that the effects of framing on the readers were not measured. Future research could be carried out to investigate the effects of magazine framing on readers.

\section{References}

Alagappar, P., \& Selvaratnam, L. (2014). Analysis of a Malaysian edition of foreign magazines in portraying women's issues. International Postgraduate Business Journal, 6(1), 49-67.

Alam, M. (2015). Gender stereotypes among university students towards masculinity and femininity. Rupkatha Journal on Interdisciplinary Studies in Humanities, 7(3), 271-283.

Arauna, T., \& Tarragona, I. (2013). Advertising stereotypes and gender representation in social networking sites. Scientific Journal of Media Education, 41(1), 177-186.

Basnyat, I., \& Chang, L. (2014). Are you a "woman"? Representation of femininity in two women's magazines in singapore, $\mathrm{Cleo}$ and $\mathrm{Her}$ World. Communication Research Reports, 31(1), 82-91.

Blu Inc, (2016). [online] Retrieved from: http://www.bluinc.com.my/wpcontent/uploads/2015/11/FEMALE-mediakit-2015.pdf
Bryant, J., \& Miron, D. (2004). Theory and research in mass communication. Journal of Communication, 54(4), 662-704.

Chan, T. (2016). Model fever. Female (September 2016), p.216.

Chong, D., \& Druckman, J. N. (2007). A theory of framing and opinion formation in competitive elite environment. Journal of Communicatrion, 57(1), 99-118.

De Vreese, C., \& Semetko, H. A. (2002). Cynical and engaged: Strategic campaign coverage, public opinion and mobilization in a referendum campaign. Communication Research, 29(6), 615-641.

Entman, R. B. (1993). Framing: Toward clarification of a fractured paradigm. Journal of Communication, 43(1), 51-58.

Gitlin, T. (1980). The whole world's watching. Berkeley and Los Angeles: University of California Press.

Goffman, E. (1974). Frame analysis: An essay on the organization of experience. Cambridge: Harvard University Press.

Govender, N., Rawjee, V., \& Govender, J. (2014). Magazines' representation of women and its influence on identity construction: A South African perspective. Mediterranean Journal of Social Sciences, 20(5), 112-119.

Griffin, E. A. (2003). A first look at communication theory. San Francisco: McGrawHill.

Grover, S., \& Hundal, B. (2014). A sociocultural examination of gender role: A study of projection of women in advertisements. Journal of Marketing and Communication, 9(3), 28-36.

Hashim, I., Azmawati, A., Endut, N., \& Aziz, S. (2016). Exploring women's relationships: An analysis of Malaysian women's lifestyle magazines. 1st International Conference on Humanities, Social Sciences and Environment, pp.9-15.

Hofstede, G. (2011). Dimensionalizing cultures: The Hofstede model in context. Online Readings in Psychology and Culture, 2(1), 3-26.

International Monetary Fund (IMF) Blog April 2, 2018. Chart of the Week: Malaysia Needs More Women in the Workforce. Retrieved from: https://blogs.imf.org/2018/04/02/chart-of- 
the-week-malaysia-needs-more-women-inthe-workforce/

Jian, G., Pettey, G., Rudd, J., \& Lawson, D. (2007). Masculinity/femininity and compliance-gaining in business negotiations: A cross-cultural comparison. Journal of the Northwest Communication Association, 36(1), 93110.

Kathiraveloo, K. (2001). Portrayal of women in women's magazine advertisements: Comparison between Her World and Wanita. Doctoral dissertation, Universiti Putra Malaysia.

Lindquist, J., Steinfeldt, K., \& BelonaxJr, J. (2015). Women's role stereotypes in magazine ads: A 25-year perspective - from Suburbia through the feminine mystique to liberation. Proceedings of the 1994 Academy of Marketing Science (AMS) Annual Conference, pp.382-385.

Milkie, M. A. (2002). Contested images of femininity: An analysis of cultural gatekeepers' struggles with the "real girl" critique. Gender E Society, 16(6), 839-859.

Moustafa, T. (2013). Islamic laws, women's rights and popular legal consciousness in Malaysia. Law E Social Inquiry, 38(1), 168-188.

O'Shaughnessy, M., \& Stadler, J. (2006). Media and society ( $3^{\text {rd }}$ Ed.). Oxford: Oxford University Press.

Ramasubramanian, S., \& Jain, P. (2009). Gender stereotypes and normative heterosexuality in matrimonial ads from globalizing India. Asian Journal of Communication, 19(3), 253-269.

Scheufele, D. A., \& Tewksbury, D. (2007). Framing, agenda setting and priming: The evolution of three media effects models. Journal of Communication, 57(1), 9-20.

Selva, J. (2016). Media planning guide Malaysia 2010. Kuala Lumpur: Perception Media Sdn Bhd.
Selvanayagam, V. (2016). Acro Pro. Female (February 2016), p.210.

Selvanayagam, V. (2016). The cool mix. Female (March 2016), p.263.

Selvanayagam, V. (2016). Speed art. Female (May 2016), p.224.

Selvanayagam, V. (2016). Striking out to success. Female (June 2016), p.198.

Tartaglia, S., \& Rollero, C. (2015). Gender stereotyping in newspaper advertisements: A cross-cultural Study. Journal of Cross-Cultural Psychology, 46(8), 1103-1109.

Tewksbury, D., Jones, J., Peske, M. W., Raymond, A., \& Vig, W. (2000). The interaction of news and advocate frames: Manipulating audience perceptions of a local public policy issue. Journalism $\mathcal{E}$ Mass Communication Quarterly, 77(4), 804-829.

Thornham, S. (2007). Women, feminism and media. Edinburgh:: Edinburgh University Press.

Tuchman, G. (2013). A handbook of media and communication research. New York: Routledge.

Van Gorp, B. (2007). The constructionist approach to framing: Bringing culture back in. Journal of communication, 57(1), 60-78.

Wimmer, R. D., \& Dominick, J. R. (2006). Mass media research: An introduction. Belmont: Wadsworth.

World Bank. (2011). World development report 2012: gender equality and development. World Bank Publications.

Yen, A. (2016). Fiery fashion. Female (November2016), p.197.

Zillman, D., Chen, L., Knobloch, S., \& Callison, C. (2004). Effects of lead framing on selective exposure to internet news reports. Communication Research, 31(1), 58-81. 